Тарабан Світлана Василівна кандидат наук з державного управління, доцент кафедри менеджменту i публічного адміністрування, Харківський національний університет міського господарства імені О. М. Бекетова, вул. Маршала Бажанова, 17, м. Харків, 61002, тел.: (050) 677-67-11, https://orcid.org/0000-0003-3417-8547

\title{
ЗАЛУЧЕННЯ ІНВЕСТИЦІЙ - ОСНОВНИЙ НАПРЯМ ДІЯЛЬНОСТІ ОРГАНІВ ПУБЛІЧНОЇ ВЛАДИ ЩОДО ЗАБЕЗПЕЧЕННЯ СОЦІАЛЬНО-ЕКОНОМІЧНОГО РОЗВИТКУ РЕГІОНУ
}

Анотація. У статті розглянуто особливості проведення інвестиційної діяльності та процеси надходження інвестицій в економіку Харківської області. Зазначено, що від ефективності організації інвестиційного процесу значною мірою залежить успішна реалізація завдань соціально-економічного розвитку регіону. Досліджено, що упродовж останніх років спостерігається суттєве зниження інвестиційної активності в Харківській області, що призвело до падіння темпів і реальних показників рівня економічного й соціального розвитку регіону. Маючи величезний потенціал, будучи регіоном-лідером в інвестиційній сфері та одним із флагманів вітчизняної економіки, Харківщина поступово почала втрачати свої позиції.

Проведено аналіз географічної структури експорту товарів Харківської області за 2020 рік і з'ясовано, що найбільш перспективними напрямами нарощування експортних поставок виступають ринки країн Азії, ринок $€ C$, a також ринки країн Близького Сходу, Африки та Латинської Америки, вихід на які став можливим за сприяння європейських та інших міжнародних партнерів. Також проаналізовано товарну структуру зовнішньої торгівлі Харківської області у 2020 році та встановлено, що найбільшу частку експорту товарів становлять продукти рослинного походження (22,6\% до загального обсягу експорту), готові харчові продукти $(22,0 \%)$ та машини, обладнання та механізми; електротехнічне обладнання $(17,1 \%)$. Зазначено, що Харківська область за підсумками 2020 року посідає дев'яте місце серед регіонів України за показником загального обсягу прямих іноземних інвестицій, залучених в область. Проаналізовано обсяги надходжень прямих інвестицій (акціонерного капіталу) з країн світу в Харківську область на кінець 2020 року і з'ясовано, що переважну частку складають надходження з країн ЄС. Досліджено напрями діяльності органів публічної влади та визначено шляхи активізації залучення прямих іноземних інвестицій для забезпечення соціально-економічного розвитку регіону. 


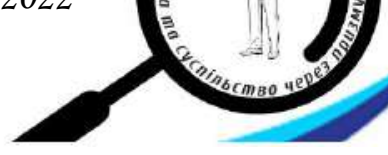

Ключові слова: прямі іноземні інвестиції, інвестиційний потенціал, інвестиційна привабливість, соціально-економічний розвиток.

Taraban Svitlana Vasylivna $\mathrm{PhD}$ in Public Administration, Associate Professor of Department of Management and Public Administration, O. M. Beketov National University of Urban Economy in Kharkiv, Marshal Bazhanov St., 17 , Kharkiv, 61002, тел.: (050) 677-67-11, https://orcid.org/0000-0003-3417-8547

\section{ATTRACTING INVESTMENTS - THE MAIN DIRECTION OF ACTIVITIES OF PUBLIC AUTHORITIES TO ENSURE SOCIAL AND ECONOMIC DEVELOPMENT OF THE REGION}

Abstract. The article considers the peculiarities of investment activity and the processes of investment in the economy of Kharkiv Region. It is noted that the successful implementation of the social economic development of the region largely depends on the effectiveness of the investment process. It is investigated that in recent years there has been a significant decline in investment activity in Kharkiv Region, which has led to the decline in the pace and real indicators of the level of economic and social development of the region. Having a huge potential, being a region-leader in the investment sphere and one of the flagships of the domestic economy, Kharkiv Region gradually began to lose its position.

The analysis of the geographical structure of the export of goods of Kharkiv Region in 2020 was carried out and it was found that the most promising directions for increasing export supplies are the markets of Asian countries, the EU market, as well as the markets of the countries of the Middle East, Africa and Latin America, access to which became possible with the assistance of European and other international partners. The commodity structure of foreign trade of Kharkiv Region in 2020 was also analyzed and it was established that the largest share of exports of goods are plant products (22.6\% of total exports), finished food products $(22.0 \%)$ and machinery, equipment and mechanisms; electrical equipment $(17.1 \%)$. It is noted that Kharkiv Region in 2020 ranks ninth among the regions of Ukraine in terms of total foreign direct investment attracted to the region. The volumes of inflows of direct investments (share capital) from the countries of the world to Kharkiv Region at the end of 2020 are analyzed and it is found out that the predominant share is inflows from the EU countries. The directions of activity of public authorities are investigated and the ways of intensification of attraction of direct foreign investments for maintenance of social and economic development of the region are defined.

Keywords: foreign direct investment, investment potential, investment attractiveness, social and economic development.

Постановка проблеми. Від ефективності організації інвестиційного процесу значною мірою залежить успішна реалізація завдань соціально- 
економічного розвитку регіону. Активізація інвестиційного процесу $\epsilon$ головною складовою економічних вимог, які покликані визначити реальні зрушення в структурі економіки країни та регіону, підвищити якість вітчизняної продукції та іiі конкурентоспроможність на світовому ринку, сприяти подоланню міжрегіональних диспропорцій, забезпечити якісне економічне зростання в державі.

Упродовж останніх років спостерігається суттєве зниження інвестиційної активності в Харківській області, що призвело до падіння темпів і реальних показників рівня економічного й соціального розвитку регіону. Харківщина зі своїм величезним потенціалом, будучи регіоном-лідером в інвестиційній сфері та одним із флагманів вітчизняної економіки, поступово почала втрачати свої позиції [1].

Традиційно на місцевому рівні низькі показники залучених інвестицій, зокрема прямих іноземних інвестицій, пов'язують із зовнішніми факторами. Проте за останні роки Україна покращила свої позиції у міжнародних рейтингах, що $\epsilon$ свідченням поліпшення інвестиційного клімату. Так, у рейтингу легкості ведення бізнесу Doing Business 2020, що його щорічно складає Всесвітній банк, Україна посіла 64 місце зі 190 країн, покращивши свої позиції на 7 пунктів, порівняно з попереднім роком [2].

Водночас на стан залучення інвестицій мають вплив й інші фактори, які стосуються, передусім, загальнонаціонального контексту, зокрема: порівняно невисокий рівень загальної інвестиційної привабливості України, пов'язаний 3 недостатньою макроекономічною стабільністю, а також недостатнім рівнем захищеності законних прав та інтересів інвесторів з боку судової системи; відсутність ефективних інвестиційних стимулів, нестача інструментів підтримки наявних та потенційних інвесторів; недостатній рівень фінансової підтримки підприємницької діяльності, що стримує створення інноваційних стартапів - компаній, привабливих для венчурних інвесторів. Тому особливої актуальності набувають питання, пов'язані 3 вивченням умов залучення інвестицій i ïx ефективним використанням, створенням сприятливого інвестиційного клімату регіону, підвищенням рівня його інвестиційної привабливості.

Аналіз останніх досліджень i публікацій. Дослідження процесів залучення інвестицій на сучасному етапі розвитку економічних відносин знайшли своє відображення у низці праць українських і зарубіжних науковців: О. Амоші, В. Василенка, О. Власюка, В. Волошина, О. Гаврилюка, П. Гайдуцького, В. Гейця, Б. Губського, Б. Данилишина, М. Денисенка, А. Дєгтяра, В. Загорського, І. Крейдич, Л. Шинкарук та ін.

Проблеми іноземного інвестування були розглянуті такими вітчизняними вченими, як А. Пересада, Н. Татаренко, М. Денисенко, Я. Жалило. 
Незважаючи на широке коло наукових напрацювань 3 питань залучення інвестицій, існує багато проблем, які вимагають подальшого дослідження умов залучення інвестицій і їх ефективного використання.

Мета статті - дослідження напрямів діяльності органів публічної влади щодо забезпечення соціально-економічного розвитку регіону, статистичний аналіз структури експорту товарів, динаміки надходжень прямих іноземних інвестицій до Харківської області та визначення шляхів активізації їх залучення.

Виклад основного матеріалу. Харківська область входить до числа найпотужніших індустріальних центрів Східної Європи.

На Харківщині сконцентровано конкурентний потенціал розвитку виробництв та сервісів, які орієнтовані на зовнішній та внутрішній ринок України і можуть забезпечити високу ефективність інвестицій.

Насамперед, перспективи регіону пов'язані 3 наукомістким машинобудуванням, сільським господарством та виробництвом продуктів харчування, газовидобуванням та енергетикою, науково-технічними розробками та освітою, галуззю IT.

Помірний клімат, рівнинний рельєф, наявність високо родючих чорноземів сприяють розвитку диверсифікованого сільського господарства. Зростання попиту на продукти харчування у світі і тенденції до споживання органічних продуктів створює можливість для розвитку сільськогосподарських підприємств, фермерських господарств та харчової промисловості.

Харківська область є логістичним центром 3 розвинутою транспортною інфраструктурою, зокрема, через наявність міжнародного аеропорту, залізничного сполучення та автомагістралей, що, у свою чергу, надає додаткове сприяння розвитку співпраці з іншими країнами світу.

Найбільш перспективними напрямами нарощування експортних поставок виступають ринки країн Азії, ринок СС, а також ринки країн Близького Сходу, Африки та Латинської Америки, вихід на які став можливим за сприяння європейських та інших міжнародних партнерів.

Географічна структура експорту товарів Харківської області за 2020 рік представлена в таблиці 1 [3]. 
Таблиия 1

Географічна структура експорту товарів Харківської області за 2020 рік

\begin{tabular}{|c|c|c|c|}
\hline & \multicolumn{3}{|c|}{ Експорт } \\
\cline { 2 - 4 } & $\begin{array}{c}\text { тис.дол. } \\
\text { США }\end{array}$ & $\begin{array}{c}\text { у \% до } \\
2019 \text { року }\end{array}$ & $\begin{array}{c}\text { у \% до } \\
\text { згального } \\
\text { обсягу }\end{array}$ \\
\hline Усього & $\mathbf{1 4 7 1 1 5 9 , 5}$ & $\mathbf{1 0 4}$ & $\mathbf{1 0 0}$ \\
\hline у тому числі & & & 15,9 \\
\hline Російська Федерація & 234072,5 & 92,6 & 7,1 \\
\hline Сгипет & 103775,1 & 78,8 & 5,1 \\
\hline Туреччина & 75676,7 & 84 & 5,0 \\
\hline Японія & 73989,7 & 103,8 & 4,2 \\
\hline Польща & 62434,4 & 102,6 & 4,0 \\
\hline Китай & 59223,7 & 169,6 & 3,7 \\
\hline Республіка Молдова & 54509 & 97,1 & 3,6 \\
\hline Білорусь & 53054,5 & 82 & 3,3 \\
\hline Грузія & 48912,5 & 88,7 & 2,2 \\
\hline Індія & 47186,1 & 88 & 2,0 \\
\hline Німеччина & 39161,6 & 110,2 & 2,0 \\
\hline Литва & 29428,2 & 128,5 & 1,7 \\
\hline Нідерланди & 28723,6 & 177,5 & 1,7 \\
\hline Італія & 24672,8 & 115,3 & 125,9 \\
\hline Азербайджан & 24642,8 & & \\
\hline
\end{tabular}

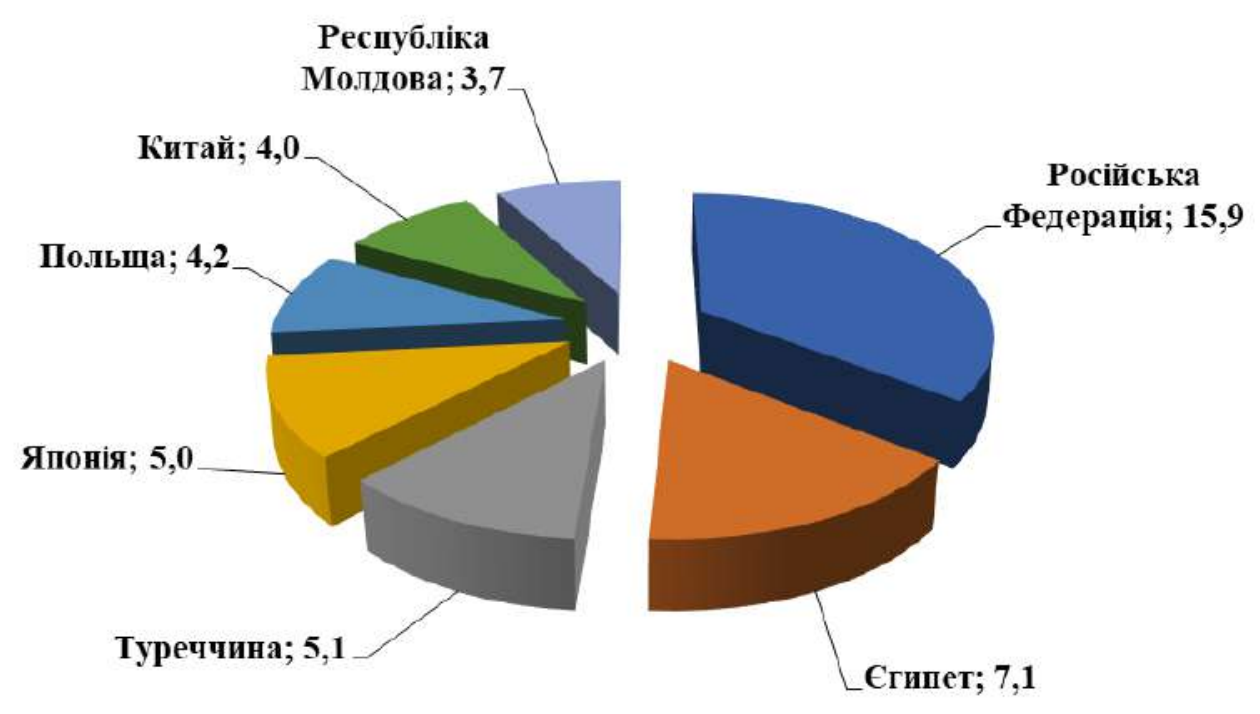

Puc. 1. Географічна структура експорту товарів Харківської області за 2020 рік (у\% до загального обсягу). 
Товарна структура зовнішньої торгівлі Харківської області у 2020 році наведена в таблиці 2 [4].

Таблиия 2

Товарна структура зовнішньої торгівлі Харківської області у 2020 році

\begin{tabular}{|c|c|c|c|}
\hline \multirow[b]{2}{*}{ Код і назва товарів згідно з УКТЗЕД } & \multicolumn{3}{|c|}{ Експорт } \\
\hline & $\begin{array}{l}\text { тис.дол. } \\
\text { США }\end{array}$ & $\begin{array}{c}\text { у \% до } \\
2019 \text { року }\end{array}$ & $\begin{array}{c}\text { у \% до } \\
\text { загального } \\
\text { обсягу }\end{array}$ \\
\hline Усього & 1471159,5 & 104 & 100 \\
\hline у тому числі & & & \\
\hline $\begin{array}{l}\text { II. Продукти рослинного } \\
\text { походження }\end{array}$ & 332175,9 & 116,1 & 22,6 \\
\hline IV. Готові харчові продукти & 323937 & 99,3 & 22,0 \\
\hline $\begin{array}{c}\text { XVI. Машини, обладнання та } \\
\text { механізми; електротехнічне } \\
\text { обладнання }\end{array}$ & 251622,5 & 95,7 & 17,1 \\
\hline $\begin{array}{c}\text { III. } 15 \text { Жири та олії тваринного або } \\
\text { рослинного походження }\end{array}$ & 107957,6 & 121,3 & 7,3 \\
\hline $\begin{array}{l}\text { XV. Недорогоцінні метали та } \\
\text { вироби з них }\end{array}$ & 66217,1 & 114,2 & 4,5 \\
\hline $\begin{array}{c}\text { VI. Продукція хімічної та } \\
\text { пов’язаних з нею галузей } \\
\text { промисловості }\end{array}$ & 60405,2 & 93,8 & 4,1 \\
\hline $\begin{array}{c}\text { VII. Полімерні матеріали, пластмаси } \\
\text { та вироби з них }\end{array}$ & 52720,2 & 116,8 & 3,6 \\
\hline $\begin{array}{l}\text { XVII. Засоби наземного транспорту, } \\
\text { літальні апарати, плавучі засоби }\end{array}$ & 48077,3 & 105,6 & 3,3 \\
\hline $\begin{array}{c}\text { XIII. Вироби з каменю, гіпсу, } \\
\text { цементу }\end{array}$ & 46222,4 & 106,5 & 3,1 \\
\hline $\begin{array}{l}\text { XI. Текстильні матеріали та } \\
\text { текстильні вироби }\end{array}$ & 44141,3 & 94,1 & 3 \\
\hline
\end{tabular}




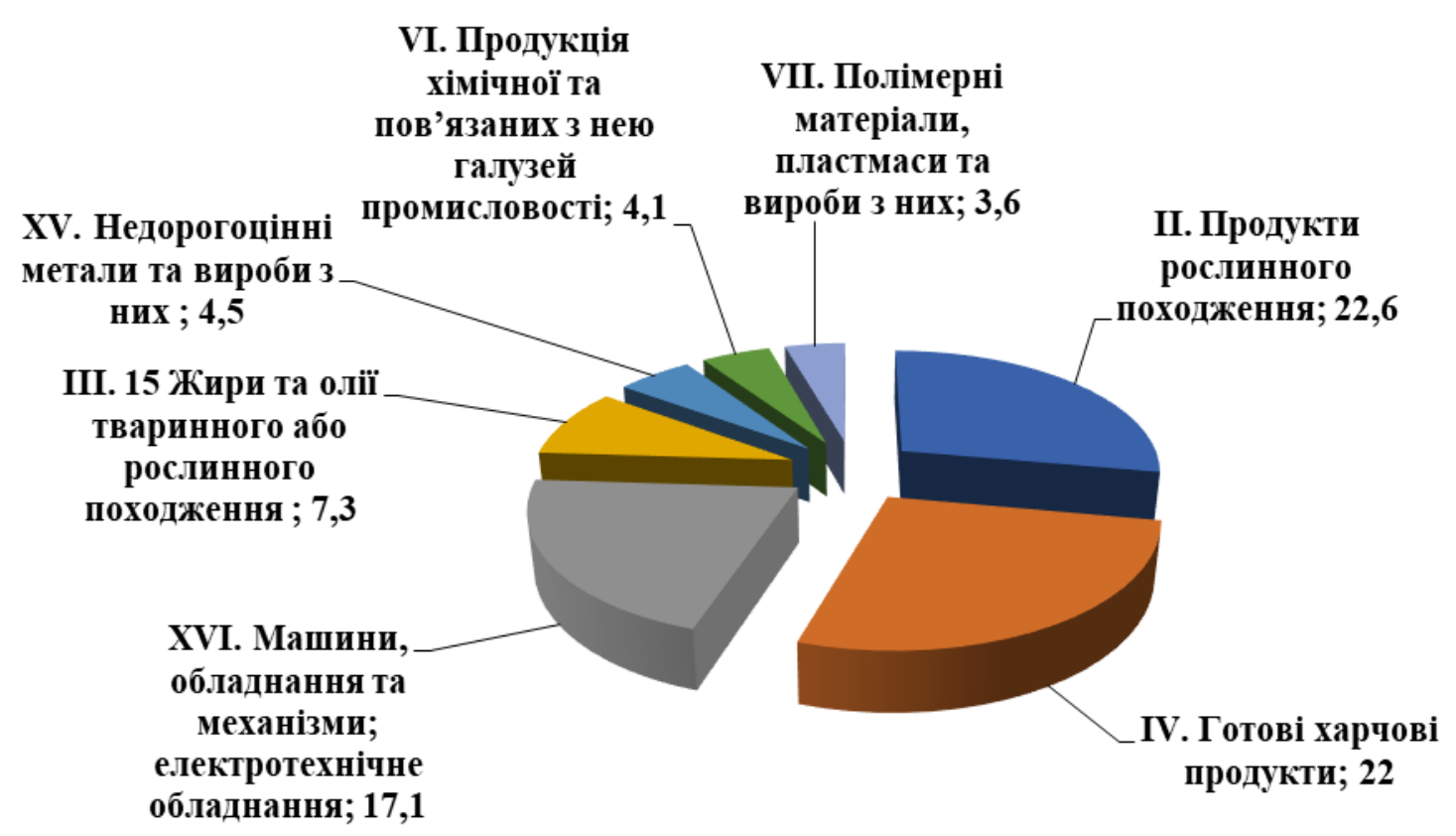

Pис. 2. Товарна структура зовнішньої торгівлі Харківської області у 2020 рочі (експорт у \% до загального обсягу).

Станом на 31 грудня 2020 року загальний обсяг прямих іноземних інвестицій (інструменти участі в капіталі), залучених в область, склав 910,4 млн. дол. США (9 місце серед регіонів України) [5].

В економіку Харківської області було внесено прямих іноземних інвестицій з країн ЄС 474,4 млн. дол. США (52,1\%), з інших країн - 436,1 млн. дол. США (47,9\%).

Динаміка надходжень прямих іноземних інвестицій до Харківської області представлена на рис. 3.

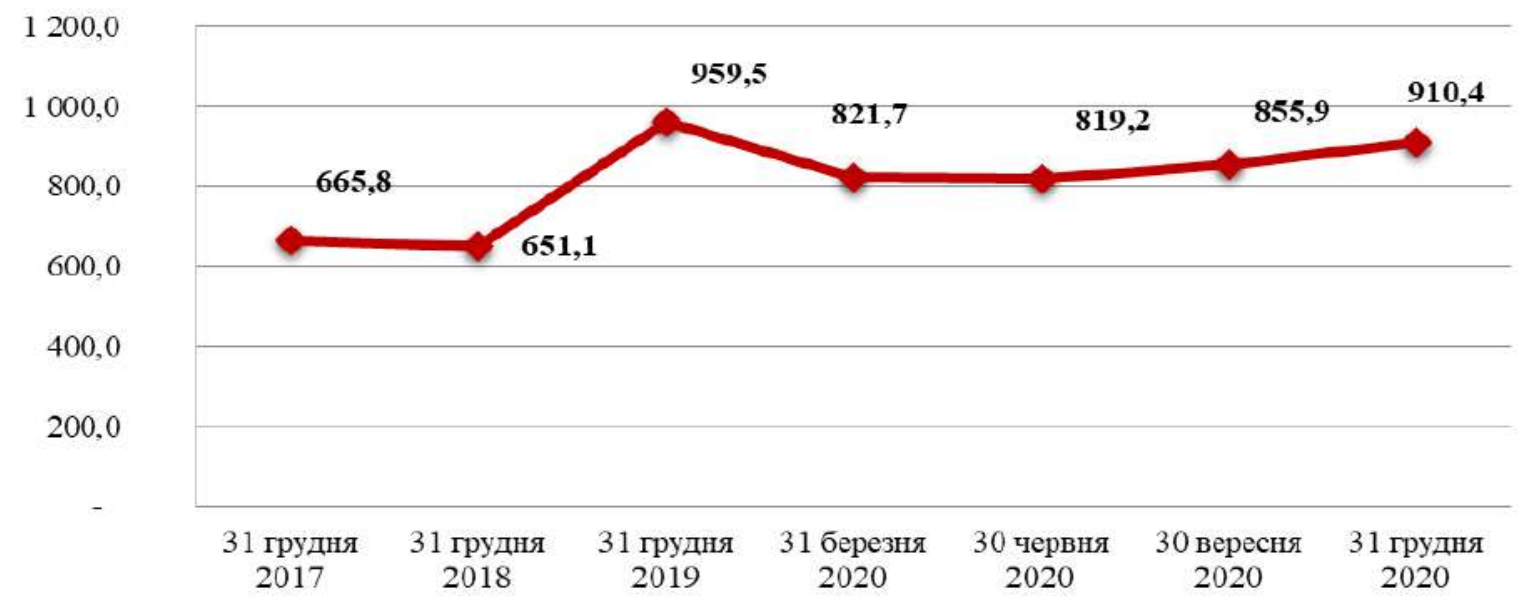

Pис. 3. Прямі іноземні інвестииї (інструменти участі в капіталі) в Харківську область (млн. дол. США) [5]. 
Розподіл прямих іноземних інвестицій в Харківську область за основними країнами-інвесторами відображено на рис. 4.

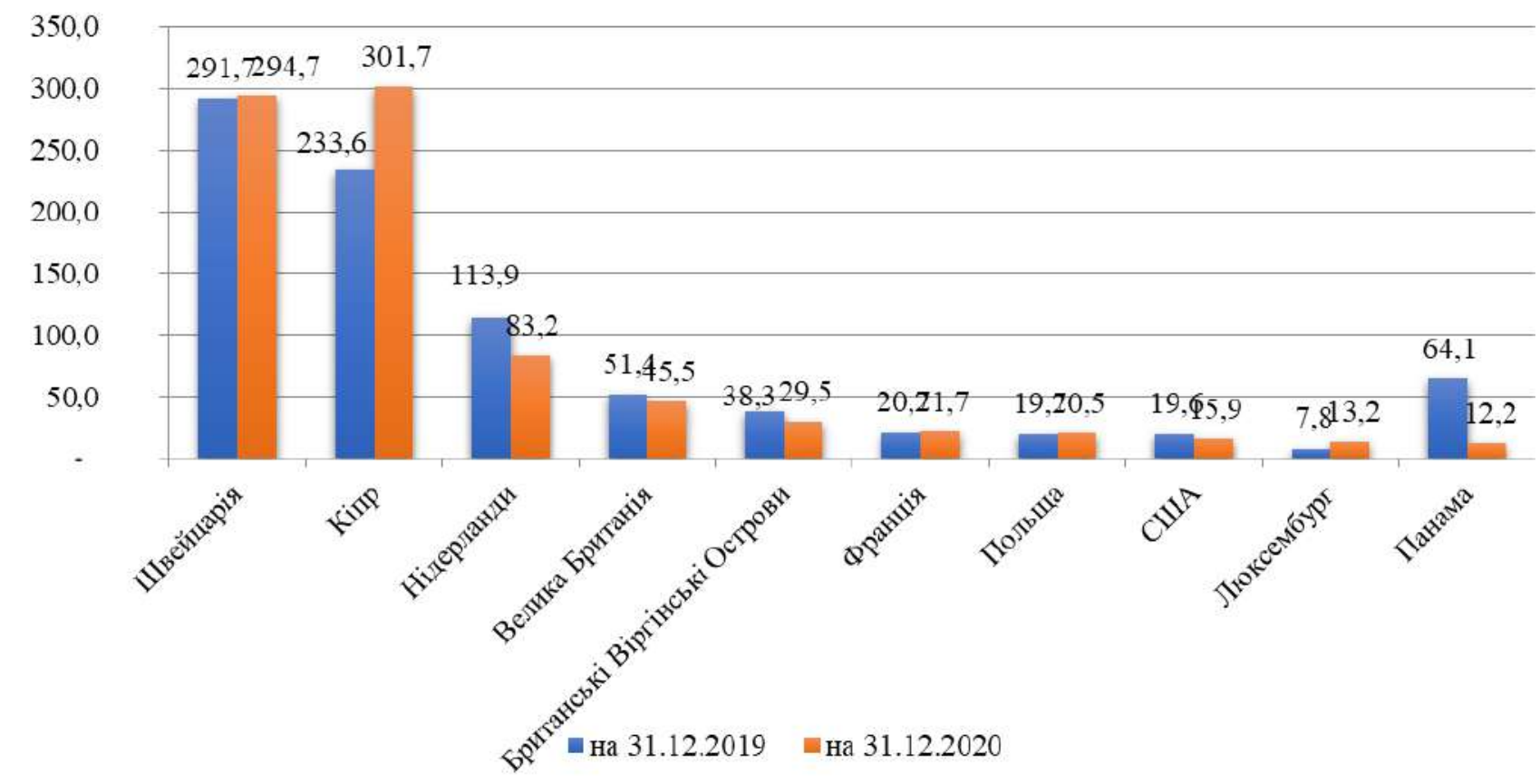

Pис. 4. Розподіл прямих іноземних інвестицій (інструменти участі в капіталі) в Харківську область за основними краӥнами-інвесторами (млн. дол. США) наростаючим підсумком з початку інвестування [5].

На рис. 5 представлено галузеву структуру іноземного капіталу Харківської області станом на 31 грудня 2020 року.

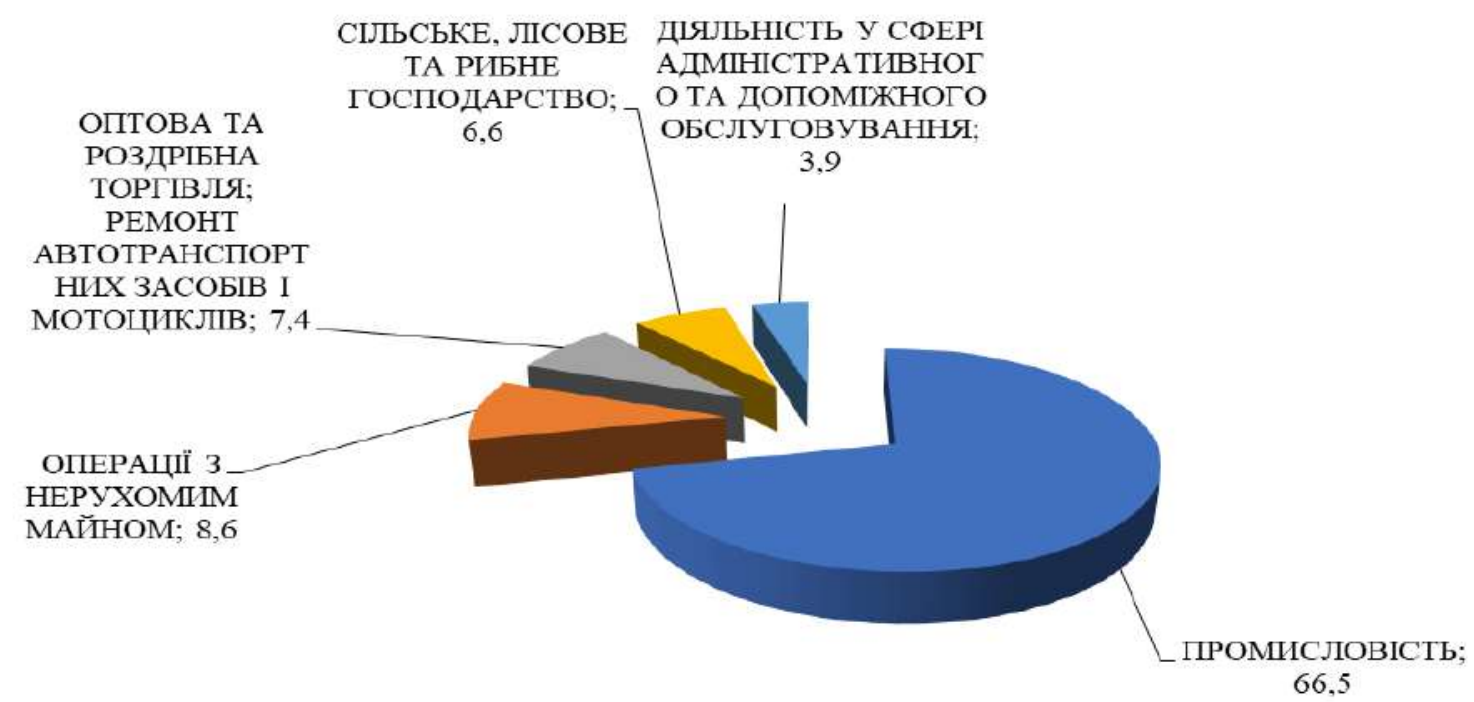

Pис. 5. Галузева структура іноземного капіталу Харківської області станом на 31 грудня2020 року, \% від загального обсягу іноземного капіталу [5]. 
Харківська область 3 їі економічним потенціалом, людським капіталом безумовно $є$ саме тим регіоном, який має всі шанси стати базовим для розвитку міжнародного бізнесу на промисловому Сході України.

Промисловість Харківської області - це ключова галузь економіки, яка забезпечує понад 50\% усіх платежів до бюджету та є основним джерелом створення робочих місць - близько $30 \%$ працюючих в області задіяно в промисловому комплексі.

В області знаходяться понад 400 великих та середніх за розмірами підприємств промисловості і понад 3,2 тис. малих підприємств, у т.ч. мікропідприємств, де працюють більше ніж 150 тис. осіб.

На промислові підприємства припадає понад 40\% реалізованої продукції Харківської області.

Індекс промислової продукції за підсумками 2020 року становив 95,8 \% (по Україні - 95,5\%). Рівень індексу промислової продукції більше 100\% забезпечили такі галузі промисловості: постачання електроенергії, газу, пари та кондиційованого повітря - $117,1 \%$; виробництво хімічних речовин і хімічної продукції - 105,8\%; виробництво гумових і пластмасових виробів, іншої неметалевої мінеральної продукції - 102,4 \%; виробництво харчових продуктів, напоїв та тютюнових виробів - 100,5\% [6].

За підсумками 2020 року реалізовано промислової продукції на загальну суму 175,7 млрд грн. Внесок Харківської області в обсяг реалізованої продукції країни складає 7,1%. За обсягами реалізованої промислової продукції область займає 5 місце серед регіонів України після Дніпропетровської області, м.Києва, Донецької та Запорізької областей.

У Харківській області є великі проєкти, реалізовані разом із бізнесом, в тому числі міжнародним. До регіону є довіра приватних та інституціональних інвесторів. Багато років успішно реалізують свої проекти у Харківській області такі провідні міжнародні компанії, як: ПрАТ «Філіп Морріс Україна», ТОВ «Нестлє Україна», ТОВ «Амкор Тобакко Пекеджинг Україна», Харківське відділення ПрАТ «Абінбев Ефес Україна», ПрАТ «Новий Стиль», ТОВ «Східно-українська компанія «Малтюроп», спільне українсько-британське підприємство «Українська чаєрозважувальна фабрика «Ахмад Ті» тощо.

Також, у 2021 році продовжується реалізація одного із наймасштабніших інвестиційних проектів Харківської області - розбудова харківського метро, кошторисна вартість якого складає 320 млн. євро, з яких 160 млн. євро було надано Свропейським інвестиційним банком та, відповідно, 160 млн. євро Європейським банком реконструкції та розвитку.

Про довіру до регіону з боку іноземних партнерів свідчить створення представництв міжнародних фінансових організацій на території Харківської області. Зокрема, вже діють представництва таких міжнародних організацій: регіональне представництво Консультативної місії Свропейського Союзу у м. Харкові; регіональне представництво офісу Європейського банку 


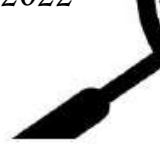

реконструкції та розвитку у Харківській області; регіональне представництво Українського національного комітету Міжнародної торгової палати в м. Харкові; регіональне представництво Фонду К. Аденауера в м. Харкові; офіс німецького товариства міжнародного співробітництва GIZ; Центр Сприяння торгівлі Соціалістичної Республіки В’єтнам у м. Харків.

Вказані структури було створено 3 метою активізації та поглиблення співробітництва з іноземними партнерами.

Про відповідний рівень довіри також свідчить присутність європейських банків у м. Харкові, таких як «Укрсиббанк» (Франція), «Ідея Банк», «Кредобанк» (Польща), «Прокредит Банк» (Німеччина), «Райффайзен Банк» (Австрія), «ОТП Банк» (Угорщина) та ін.

Формування та підтримка позитивного іміджу Харківської області та презентація іiі інвестиційного потенціалу постійно здійснюється обласною державною адміністрацією під час міжнародних економічних форумів, конференцій, ділових місій, зустрічей, а також шляхом поширення інформації щодо інвестиційних можливостей регіону серед потенційних інвесторів як на території України, так і за іï межами.

Так, керівництвом обласної державної адміністрації протягом 2020 року було проведено низку зустрічей, в тому числі у форматі відеозв'язку, 3 офіційними представниками іноземних країн таких, як Азербайджанська Республіка, Республіки Албанія, Грузія, Держава Ізраїль, Естонська Республіка, Королівство Нідерландів, Латвійська Республіка, Литовська Республіка, Республіка Польща, Сполучене Королівство Великої Британії та Північної Ірландії, Республіка Корея, Французька Республіка, Федеративна Республіка Німеччина, Киргизька Республіка, Республіка Таджикистан, Республіка Узбекистан, Чеська Республіка, Японія, а також міжнародних організацій та іноземних компаній: Східний регіональний хаб Програми «U-LEAD з Свропою», Програма USAID «DOBRE» в Україні, Місія ОБСС в Україні, Американська торгівельна палата в Україні, Офіс Управління ООН з обслуговування проєктів в Україні, Китайська Торгова Асоціація, Представництво СБРР у країнах Східної Європи та Кавказу, компанія «Nestle» тощо.

3 метою активізації роботи у сфері інвестиційної діяльності та створення позитивного інвестиційного іміджу регіону обласною державною адміністрацією проводились міжнародні заходи.

Зокрема, 24-26 березня 2021 року у Харкові, за підтримки обласної державної адміністрації, проведено Міжнародну спеціалізовану промислову виставку-форум «Kharkiv Prom Days 2021» (далі - Форум). Основною метою Форуму було налагодження комунікації між підприємствами та потенційними замовниками, висвітлення технологічних можливостей підприємств Харківської області в промисловій сфері.

Формат заходу передбачав, паралельно 3 виставкою продукції підприємств - учасників, он-лайн презентації найбільших промислових 
підприємств Харківської області для іноземних замовників.

Всього у роботі Форуму прийняли участь представники 20 країн близького та далекого зарубіжжя, у тому числі посли іноземних держав в Україні: Ісламської Республіки Пакистан, Південно-Африканської Республіки; заступники голів місій Посольства Королівства Марокко та Посольства Естонської Республіки в Україні, радник Посольства Киргизької Республіки в Україні, керівник Польської агенції з інвестицій та торгівлі в Україні; Перший Секретар, консул Генерального консульства Республіки Польща в Харкові; почесні консули Республіки Албанія та Республіки Казахстан в Харкові.

Іноземними фахівцями для учасників форуму були проведені семінари: «Сертифікація виробництв для виходу на ринки Європи», «Підготовка української компанії до виходу на ринок країн GCC. Приклад Саудівської Аравії», «Співпраця Україна-Італія» та «Особливості співпраці Україна Африка». Також, під час заходу відбулись індивідуальні онлайн-переговори учасників Форуму з діловими партнерами у форматі В2В.

Виставка пройшла за участю представників посольств, торгових палат та бізнес-місій Пакистану, Туреччини, Німеччини, Італії, КНР, Саудівської Аравії, Ізраїлю та інших зацікавлених у співробітництві країн. В роботі виставки прийняли участь представники Міністерства 3 питань стратегічних галузей промисловості України та керівники 15 найбільших закладів вищої освіти м.Харкова. На виставці була представлена продукція та презентовані технологічні можливості 38 промислових підприємств Харківщини.

Вагомим фактором підвищення інвестиційної привабливості Харківської області є затвердження у березні 2021 року Програми розвитку інвестиційної діяльності Харківської області на 2021-2024 роки [1], яка розроблена на основі стратегічних пріоритетів та цілей Стратегії розвитку Харківської області на 2021 - 2027 роки [7] та Плану заходів на 2021 - 2023 роки з реалізації Стратегії розвитку Харківської області на 2021-2027 роки [8], з урахуванням положень Державної стратегії регіонального розвитку України на 2021-2027 роки [9].

Програма $\epsilon$ одним із основних засобів реалізації Стратегії розвитку Харківської області на 2021-2027 роки. Стратегічна ціль зазначеної Програми щодо забезпечення інвестиційно-привабливого клімату в регіоні і створення інноваційної та інвестиційної інфраструктури поєднує ряд операційних цілей i завдань, спрямованих на забезпечення позиціонування Харківщини як найкращого місця для вкладання інвестицій та створення необхідних умов для інвестування.

\section{Висновки.}

Залучення інвестицій в Харківський регіон завжди було і $є$ одним 3 головних пріоритетів діяльності місцевих органів влади.

Харківська область має сильні сторони порівняно 3 іншими регіонами країни з точку зору привабливості для іноземних інвесторів.

Сильною стороною області $є$ наявність великої кількості наукових та освітніх установ європейського рівня. Економіка області має значний рівень 
диверсифікації та індустріалізації, у промисловості переважають переробні галузі, зокрема, машинобудування.

Активізація співробітництва 3 країнами світу, залучення іноземних i внутрішніх інвестицій підтримуватимуть розвиток високотехнологічних галузей та сприятимуть підвищенню інноваційної активності підприємств.

В області сконцентрована значна частка IT-фахівців країни та освітніх установ, які забезпечують їх підготовку. В умовах повної діджиталізації виробництва і сфери урядування ця сильна сторона є конкурентною перевагою області для залучення інвестицій. Новітні розробки, програмні продукти та системні рішення управлінських, виробничих та бізнес процесів в регіоні, наряду 3 іншими, активно використовуються в промисловості, сільському господарстві та у сферах обслуговування населення.

Наявність покладів енергетичних корисних копалин за умови послідовної державної підтримки забезпечить області підвищення рівня енергонезалежності у споживчій та виробничій сферах.

В ході реалізації Програми розвитку інвестиційної діяльності Харківської області на 2021-2024 роки необхідно досягти значно вищої ефективності в економічній та інвестиційній політиці регіону, що дозволить забезпечити покращення ділового та інвестиційного іміджу області та поширення в світі об'єктивної інформації про регіон як надійного, стабільного та передбачуваного партнера. Реалізація Програми стане механізмом суттєвої активізації інвестиційної діяльності та залучення приватних інвестицій, зокрема й прямих іноземних інвестицій.

Харківська обласна державна адміністрація спільно 3 Харківською обласною радою, органи місцевого самоврядування на місцях, маючи на меті досягнення стратегічно важливих цілей розвитку регіону, територіальні громади повинні забезпечити для інвесторів привабливість стосовно вкладання коштів у регіональну економіку, гарантувати безпеку ведення бізнесу, виступати як рівноправні партнери.

\section{Jimepamypa:}

1. Програма розвитку інвестиційної діяльності Харківської області на 2021-2024 роки. URL: https://ts.lica.com.ua/?type=1\&base=77\&menu=379623\&id=19885

2. Doing Business 2020. URL: https://www.doingbusiness.org/en/reports/globalreports/doing-business-2020

3. Географічна структура зовнішньої торгівлі товарами Харківської області у 2020 році (за уточненими даними). URL: http://kh.ukrstat.gov.ua/heohrafichna-struktura-zovnishnoitorhivli-tovaramy-kharkivskoi-oblasti-u-2018-rotsi-za-utochnenymy-danymy

4. Товарна структура зовнішньої торгівлі Харківської області у 2020 році (за уточненими даними). URL: http://kh.ukrstat.gov.ua/tovarna-struktura-zovnishnoi-torhivlikharkivskoi-oblasti-u-2018-rotsi-za-utochnenymy-danymy

5. Статистика зовнішнього сектору України за методологією 6-го видання "Керівництва 3 платіжного балансу та міжнародної інвестиційної позиції" (МВФ, 2009). Національний банк України. URL: https://bank.gov.ua/ua/statistic/sector-external/data-sector-external\#1 
6. Головне управління статистики у Харківській області. URL: http://kh.ukrstat.gov.ua

7. Стратегія розвитку Харківської області на 2021-2027 роки. URL: http://www.kharkivoda.gov.ua

8. План заходів на 2021 - 2023 роки з реалізації Стратегії розвитку Харківської області на 2021-2027 роки. URL: http://www.kharkivoda.gov.ua

9. Державна стратегія регіонального розвитку України на 2021-2027 роки. URL: https://zakon.rada.gov.ua/laws/show/695-2020-\%D0\%BF\#Text

\section{References:}

1. Programa rozvitku investicijnoï dijal'nosti Harkivs'koï oblasti na 2021-2024 roki [The program of development of investment activity of the Kharkiv region for 2021-2024]. Retrieved from: https://ts.lica.com.ua/?type=1\&base=77\&menu=379623\&id=19885 [in Ukrainian].

2. Doing Business 2020. Retrieved from: https://www.doingbusiness.org/en/reports/globalreports/doing-business-2020 [in English].

3. Geografichna struktura zovnishn'oï torgivli tovarami Harkivs'koï oblasti u 2020 roci (za utochnenimi danimi) [Geographical structure of foreign trade in goods of Kharkiv region in 2020 (according to updated data)]. Retrieved from: http://kh.ukrstat.gov.ua/heohrafichna-struktura-zovnishnoitorhivli-tovaramy-kharkivskoi-oblasti-u-2018-rotsi-za-utochnenymy-danymy [in Ukrainian].

4. Tovarna struktura zovnishn'oï torgivli Harkivs'koï oblasti u 2020 roci (za utochnenimi danimi) [Commodity structure of foreign trade of Kharkiv region in 2020 (according to updated data)]. Retrieved from: http://kh.ukrstat.gov.ua/tovarna-struktura-zovnishnoi-torhivli-kharkivskoioblasti-u-2018-rotsi-za-utochnenymy-danymy [in Ukrainian].

5. Statistika zovnishn'ogo sektoru Ukraïni za metodologiєju 6-go vidannja "Kerivnictva z platizhnogo balansu ta mizhnarodnoï investicijnoï poziciï" (MVF, 2009). Nacional'nij bank Ukraïni [Statistics of the external sector of Ukraine according to the methodology of the 6th edition of the "Balance of Payments and International Investment Position" (IMF, 2009). National Bank of Ukraine]. Retrieved from: https://bank.gov.ua/ua/statistic/sector-external/data-sector-external\#1 [in Ukrainian].

6. Golovne upravlinnja statistiki u Harkivs'kij oblasti [Main Department of Statistics in Kharkiv region]. Retrieved from: http://kh.ukrstat.gov.ua [in Ukrainian].

7. Strategija rozvitku Harkivs'koï oblasti na 2021-2027 roki [Development strategy of Kharkiv region for 2021-2027]. Retrieved from: http://www.kharkivoda.gov.ua [in Ukrainian].

8. Plan zahodiv na 2021 - 2023 roki z realizaciï Strategii rozvitku Harkivs'koï oblasti na 2021-2027 roki [Action plan for 2021 - 2023 on the implementation of the Development Strategy of Kharkiv region for 2021-2027]. Retrieved from: http://www.kharkivoda.gov.ua [in Ukrainian].

9. Derzhavna strategija regional'nogo rozvitku Ukraïni na 2021-2027 roki [State strategy of regional development of Ukraine for 2021-2027]. Retrieved from: https://zakon.rada.gov.ua/ laws/show/695-2020-\%D0\%BF\#Text [in Ukrainian]. 